\title{
Analysis of a monetary union enlargement in the framework of linear-quadratic differential games
}

\author{
Joseph Plasmans • Jacob Engwerda • \\ Bas van Aarle • Tomasz Michalak
}

Published online: 17 June 2009

(C) The Author(s) 2009. This article is published with open access at Springerlink.com

\begin{abstract}
This paper studies the effects of a monetary union enlargement using the techniques and outcomes from an extensive research project on macroeconomic policy coordination in the EMU. Our approach is characterized by two main pillars: (i) linear-quadratic differential games to capture externalities, spillovers and strategic behaviour of (fiscal and monetary) players; and (ii) endogenous coalition formation concepts which enable us to study a creation and stability of different cooperation arrangements. In this paper we focus on the first pillar and construct a multi-player linear-quadratic continuous-time model of 5 countries and 4 central banks to evaluate effects of accession of a new member to an existing MU. Our findings stress the importance of an asymmetric shock confirming basic results of the OCA theory. It comes out that in our setting it is never profitable to enlarge the monetary union when there is a risk of an asymmetric shock. What is more, the potential losses from accession are so high that it can be barely possible to design a transfer system to compensate for a worse situation of some countries.
\end{abstract}

Bas van Aarle and Tomasz Michalak acknowledge the financial support from the FWO (Fonds voor Wetenschappelijk Onderzoek Vlaanderen).

\footnotetext{
J. Plasmans

University of Antwerp and Tilburg University, Antwerp, Belgium

J. Engwerda

Tilburg University, Tilburg, The Netherlands

B. van Aarle

European Business School, Wiesbaden, Germany

T. Michalak

Universities of Antwerp and Liverpool, Liverpool, UK

J. Plasmans $(\square)$

Department of Economics, University of Antwerp, Prinsstraat 13, B2000 Antwerp, Belgium

e-mail: joseph.plasmans@ua.ac.be
} 
Keywords Macroeconomic stabilization · EMU · Optimal currency area ·

Linear quadratic differential games.

JEL codes: $\mathrm{C} 70 \cdot \mathrm{E} 17 \cdot \mathrm{E} 58 \cdot \mathrm{E} 61 \cdot \mathrm{E} 63$

\section{Introduction}

The fourth enlargement of the European Union (EU) on the 1st of May 2004 was by any standard the most pervasive and diverse of all EU-enlargements in history. ${ }^{1}$ Among many other obligations, new member states have also committed themselves to join the European Economic and Monetary Union (EMU) as soon as they have fulfilled the entry conditions laid down in the Treaty of Maastricht. These so-called Maastricht Criteria (EU, 1992, article 109 j (1)) provided fiscal convergence criteria in terms of inflation, interest rates, debt and deficits for the countries to qualify for entrance into the EMU. ${ }^{2}$ Depending on the amount of effort that countries invest in complying with these entrance criteria there is a certain degree of freedom in choosing the exact point in time at which to enter. In the fastest track e.g. countries would comply immediately and enter the euro area in the second half of 2006. In fact, Slovenia entered as the first new EU member state on the 1st of January 2007, while Malta and (the Greek part of) Cyprus did so on the 1st of January 2008, and Slovakia on the 1 st of January $2009 .{ }^{3}$ Bohn (2004) rightly asserts regarding the prospective acceding countries: "However, care must be taken to avoid recession or overheating effects, in case interest and exchange rate impulses reinforce one another (instead of exhibiting trade-off effects). The right timing for joining a monetary union (MU henceforth) is crucial, if policymakers want to make sure that conditions are advantageous for all countries involved."

Moreover, it is very unlikely that a single strategy could be recommended to all acceding countries regarding macroeconomic stabilization on the road to the euro. Arguments in favor of adopting the euro as early as possible include a smaller financial risk due to the elimination of a currency mismatch in the balance sheets of banks and firms, interest rate convergence and overall gains in monetary credibility, while arguments for a slower pace to the euro include the need to remove financial distortions creating moral hazard and therefore raising the country's default risk, easier relative-price adjustment without the need of costly nominal wage and price adjustments and the need to make fiscal and financial policy sustainable and compatible with a fixed exchange rate before participation in the EMU. The

\footnotetext{
${ }^{1}$ The earlier enlargements in 1981-86 and in 1995 involved only three countries each. The 2004 enlargement raised the EU population to about 480 million people from 375 million in the EU-15 countries.

${ }^{2}$ Hughes Hallett and McAdam (1997) and von Hagen and Lutz (1996) e.g. investigated the macroeconomic repercussions of implementing the fiscal convergence criteria of the Maastricht Treaty in the EMU-12.

3 According to the Maastricht Treaty a candidate country should participate in the Exchange Rate Mechanism II (ERM II) without major tensions in the foreign exchange market. ERM II replaced the ERM of the European Monetary System created in 1979. ERM II was established in 1997 with the resolution of the European Council in order to link the currencies of the EU member states outside the euro area and the euro. Like ERM I, ERM II is also a multilateral exchange rate arrangement with a fixed, but adjustable, central parity and a fluctuation band around it. Countries participating in ERM II peg their exchange rates to the euro, allowing for fluctuations within a symmetric band of 15 percent on each side of the central parity.
} 
European Economic Advisory Group at CESifo recommends in its 2004 Report on the European Economy (p. 135) that: "Delaying participation in ERM II is a realistic option for countries that are currently unable to sustain hard pegs and have large domestic imbalances. The magnitude of domestic imbalances varies considerably across countries, so that ERM entry may be desirable at different times. Yet in all cases, the policy priority is achieving a sustainable fiscal situation and stabilizing inflation at the correct relative prices, a task that requires both institutional and policy reforms."

Several studies have analyzed the degree to which the accession countries may form an OCA with the current euro area. In terms of trade interdependence and business cycle convergence with the $\mathrm{E}(\mathrm{M}) \mathrm{U}$, the accession countries reach comparable scores like current member countries (see e.g. Boone and Maurel (1999)). On the other hand, the degree of symmetry of shocks is generally found to be lower (see e.g. Fidrmuc and Korhonen (2001)). The latter finding may be problematic in the sense that the accession countries by acceding to the euro area give up national monetary policy independence and in particular the possibility of exchange rate adjustment vis-à-vis the euro area in case they experience asymmetric shocks. Upon accession, their monetary policy will be set by the ECB. In addition, the accession countries will adopt the fiscal policy cooperation and surveillance procedures of the Stability and Growth Pact. During the recent years, monetary policy in the accession countries have displayed a large variation ranging from very strict euro pegging in the form of a currency board in small accession countries such as Estonia to informal euro target zones in larger accession countries like Poland (see European Parliament (1999) for a detailed account). As a consequence of fixed bilateral exchange rates, asymmetric shocks have long been seen as the major problem for the EMU (see Favero et al. (2000)). It is generally argued that this kind of externalities can be coped by structural reforms that have been advocated to improve flexibility on product and labor markets. However, an alternative way resides in the adoption of coordinated policies among EU member countries.

This paper is based on the results from an extensive research project on macroeconomic policy coordination in the presence of an MU. ${ }^{4}$ The detailed coverage of research techniques and outcomes can be found in Plasmans et al. (2006) and on the internet. ${ }^{5}$ In this analysis we aim to shed some more light on issues of macroeconomic shocks in the monetary area and the effects of its enlargement. To take into account spillovers, externalities and strategic behaviour of different (self-oriented) players, we construct a multi-country continuous-time model of 5 countries and 4 central banks. Moreover, we solve the resulting differential game for some (the most plausible) coalition structures in order to model effects of various cooperative arrangements between players. ${ }^{6}$ Such arrangements, in pre- and post-accession stages, may have substantial impact on profitability of accession. Finally, we compare the (optimal) losses caused by the same

\footnotetext{
${ }^{4}$ This research project titled "Endogenous Coalition Formation in a European Stabilization Policy Setting: Feasibility and Effects" (University of Antwerp and Tilburg University) is financed by the Flemish Science Foundation (FWO). Predecessors of the project are Engwerda et al. (1999, 2002).

${ }^{5}$ See www.ua.ac.be/joseph.plasmans.

${ }^{6}$ In this paper we restrict our attention to profitability of accession. We do not consider stability of different coalition structures or other issues (e.g. institutional) of policy coordination. For an application of endogenous coalition formation concepts in this setting see Plasmans et al. (2006), Michalak et al. (2006), Di Bartolomeo et al. (2006) and van Aarle et al. (2002, 2004).
} 
shock in the pre-accession stage and in the post-accession stage. The differences between both stages need to be completely attributed to the accession of the MU by a new member.

In this way we can also directly calculate in the model the net benefits of accession for each player.

The analysis is structured as follows: Section 2 provides a $n$-country dynamic macroeconomic model that underlies the analysis in this paper. Section 3 analyzes the policy coordination issues that arise in an MU. In particular, we focus on the institutional setup and cooperative mechanisms in the MU. Section 4 introduces main issues related to the enlargement of the MU. Numerical simulations in Section 5 illustrate the functioning of the model using specific examples. The conclusion summarizes the main insights.

\section{The basic economic framework}

Our analytical framework is presented in its most general form, from which various specific settings can directly be chosen, e.g. by varying the number of countries and MUs and types of policy cooperation. Assume that players from the set $N$ interact. They can be divided in two groups: $\mathrm{n}_{\mathrm{f}}$ countries $f(f \in F)$ and $n_{b}$ central banks $b(b \in$ $B$, with $N=F \cup B$ ). Each bank is responsible for a monetary policy management in one country or in a group of countries. More formally:

Definition 1 (Bank jurisdictional set) The set of all the countries for which a bank $b$ is liable is called a bank- $b$ jurisdictional set $(B J S)$ and is denoted by $B J S(b)$. More formally, $B J S(b):=\left\{j^{b} \in N\right\}$.

Clearly, each MU consists of the following set of players $\{B J S(b), b\}$. In particular, if bank $b$ is responsible for monetary policy management in only one country, i.e. $|B J S(b)|=1$ or $B J S(b)=\left\{j^{\mathrm{b}}\right\}$, we say that players from set $\left\{j^{\mathrm{b}}, b\right\}$ constitute a trivial MU. A non-trivial MU consists of the set of players $\{B J S(b), b\}$ such that $|B J S(b)| \geq 2$.

Considering the above definition, we describe each economy $j^{\text {b }}$, i.e. each economy $j$ for which central bank $b$ is liable, by an aggregate demand/IS curve and an aggregate supply curve, which are a function of the domestic real interest rate, the domestic real fiscal deficit, the foreign real outputs (i.e. real output gaps), and the real exchange rates (measuring international competitiveness):

$$
\begin{aligned}
y_{j^{b}}(t)= & -\gamma_{j^{b}}\left[i_{j^{b}}(t)-\dot{p}_{j^{b}}(t)\right]+\eta_{j^{b}} f_{j^{b}}(t) \\
& +\sum_{\ell \in F / j^{b}} \rho_{j^{b}} y_{\ell}(t)+\sum_{\ell \in F / j^{b}} \delta_{j^{b} \ell}\left[e_{j^{b}}(t)+p_{\ell}(t)-p_{j^{b}}(t)\right]
\end{aligned}
$$

in which $y$ denotes the real output gap (defined as real output with respect to potential real output), $f$ the real fiscal deficit, $p$ the price level, $i$ the nominal interest rate, and $e$ the nominal exchange rate.

Real exchange rates are nominal exchange rates adjusted for relative prices and they measure the international competitiveness of the economy. Nominal exchange 
rates are determined according to the uncovered interest-rate parity (UIP) hypothesis, so that they adjust to corresponding interest-rate differentials:

$$
\dot{e}_{j^{b}}(t)=i_{j^{b}}(t)-i_{\ell^{b^{\prime}}}(t), \quad e_{j^{b}}(0)=e_{j^{b} 0},
$$

where the foreign currency of the nominal exchange rate is under the jurisdiction of central bank $b^{\prime} \neq b$ and where $i_{j}(t)$ is the nominal interest rate valid for country $j^{b}$ at time $t .^{7}$ The initial values of the exchange rates represent (initial) level shocks that hit the relevant exchange rates at time zero, reflecting e.g. (initial) shocks in international financial markets, etc. In an open-MU setting, the external exchange rate of the MU with non-MU countries becomes a new shock absorber vis-á-vis the transmission mechanism of monetary policy.

Equations (3) are open-economy Phillips (or supply) curves:

$$
\dot{p}_{j^{b}}(t)=\varsigma_{j^{b}} y_{j^{b}}(t)+\sum_{\ell \in F / j^{b}} \varsigma_{j^{b} \ell}\left(\dot{e}_{\ell}(t)+\dot{p}_{\ell}(t)\right), \quad p_{j^{b}}(0)=p_{j^{b} 0 .} .
$$

The Phillips curve gives rise to a short-run relation between inflation and output (gap) which results from the existence of some (nominal) rigidities in the goods and/or labor markets. In the Phillips relationship (3) the inflation rates of the other countries play a role reflecting the effects of "pass-through" of foreign inflation and depreciation of the domestic currency on domestic prices. In accordance with our short-run stabilization focus, the effectiveness of fiscal policy is limited to its transitory impact on output through the induced stimulus of the aggregate demand. The initial values of domestic prices represent (initial) level shocks that hit the economy at time zero. In this setting both symmetric and asymmetric price shocks can be considered.

We assume that the fiscal authorities $j^{b}$ control their fiscal policy instrument such as to minimize the following quadratic loss function, which features domestic inflation, real output (gap), and the real fiscal deficit, with respect to the control variable $f_{j}$ :

$$
J_{j^{b}}\left(t_{0}\right)=\frac{1}{2} \int_{t_{0}}^{\infty}\left\{\alpha_{j^{b}} \dot{p}_{j^{b}}^{2}(t)+\beta_{j^{b}} y_{j^{b}}^{2}(t)+\chi_{j^{b}} f_{j^{b}}^{2}(t)\right\} e^{-\theta\left(t-t_{o}\right)} d t \text { and }
$$

Central banks (CBs), which are responsible for monetary management in only one country (i.e., are $\mathrm{CBs}$ of a trivial $\mathrm{MU}$ ), feature the following form of loss function:

$$
J_{j^{b}}^{M}\left(t_{0}\right)=\frac{1}{2} \int_{t_{0}}^{\infty}\left\{\alpha_{j^{b}}^{M} \dot{p}_{j^{b}}^{2}(t)+\beta_{j^{b}}^{M} y_{j^{b}}^{2}(t)+\chi_{j^{b}}^{M} i_{j^{b}}^{2}(t)\right\} e^{-\theta\left(t-t_{o}\right)} d t .
$$

The loss function of a $\mathrm{CB}$ which is responsible for a monetary policy management in an MU $u \in U$ can be written as:

$$
\begin{aligned}
J_{u}\left(t_{0}\right) & =\frac{1}{2} \int_{t_{0}}^{\infty}\left\{\alpha_{u}^{M} \dot{p}_{u}^{2}(t)+\beta_{u}^{M} y_{u}^{2}(t)+\chi_{u}^{M} i_{u}^{2}(t)\right\} e^{-\theta\left(t-t_{0}\right)} d t \\
& =\frac{1}{2} \int_{t_{0}}^{\infty}\left\{\alpha_{u}^{M} \bar{P}_{u}^{2}(t)+\beta_{u}^{M} \bar{Y}_{u}^{2}(t)+\chi_{u}^{M} i_{u}^{2}(t)\right\} e^{-\theta\left(t-t_{0}\right)} d t,
\end{aligned}
$$

\footnotetext{
${ }^{7}$ If there is only one non-trivial $\mathrm{MU} u$ (with $k$ countries) involved in the model and if the currency of this MU is the currency in which the exchange rates of the non-MU countries are expressed, we can simply rewrite the UIP hypothesis (2) as: $\dot{e}_{j}(t)=i_{j}(t)-i_{U}(t), e_{j}(0)=e_{j 0}(j=1,2, \ldots, n-k+1)$, where $i_{U}(t)$ is the common nominal interest rate in the MU. $u$ (if $\dot{e}_{j}(t)>0$ we have an appreciation of the currency of the MU, while we have a depreciation of the MU currency in the opposite case $\left(\dot{e}_{j} b(t)<0\right)$.
} 
where $\bar{P}_{u}(t)$ and $\bar{Y}_{u}(t)$ are average inflation and output in MU $u$ respectively, defined as $\bar{P}_{u}(t):=\sum_{j^{u}=1}^{k_{u}} \omega_{j^{u}}{\dot{p^{u}}}_{j^{u}}(t)$ and $\bar{Y}_{u}(t):=\sum_{j^{u}=1}^{k_{u}} \omega_{j^{u}} y_{j^{u}}(t)$ with $k_{u}$ being the number of countries, that belong to $\mathrm{MU} u$, i.e $k_{u}=|B J S(b)|$, where $b$ is a central bank of MU $u$, and $\omega_{j_{u}}$ is the weight of country $j^{u}$ in the MU aggregate (e.g., its GDP share)

Theoretically speaking, any subset of the $n_{f}$ countries in the model could decide to form an MU, there could be several MUs at the same time, there could exist none at all or there could exist just one containing either a subset of countries or all the countries, in which case we would have one world currency. For clarity, we concentrate on the situation that there is only one MU, i.e., the set $U$ contains only one element.

As shown in Appendix B, ${ }^{8}$ the structural-form model (1)-(3) can be transformed for one MU into the following reduced form model:

$$
\left[\begin{array}{l}
y(t) \\
\dot{p}(t) \\
\dot{e}(t)
\end{array}\right]=\left[\begin{array}{lll}
D & E & M \\
A & B & N
\end{array}\right]\left[\begin{array}{l}
p(t) \\
e(t) \\
f(t) \\
i(t)
\end{array}\right],
$$

where $y(t), p(t)$, and $f(t)$ are the country-ordered vectors of real outputs, (output gaps), prices, and real net- government expenditures, respectively, and $e(t)$ and $i(t)$ are the mixed MU/country- ordered vectors of exchange rates and interest rates. ${ }^{9}$ The partitioned matrix $L:=\left[\begin{array}{ccc}D & E & M \\ A & B & N\end{array}\right]$ contains the elasticities of the price levels and control instruments with respect to the real output gap and inflation. The upper part of matrix $L \in \mathbb{R}^{\left(2 n_{f}+n_{b}\right) \times\left(2 n_{f}+2 n_{b}\right)}$ indicates the instantaneous elasticities with respect to the real output gaps. The lower part of the matrix indicates the elasticities with respect to the price and exchange-rate dynamics of the model. Matrix $L$ is crucial in the analysis of the spillovers. More in detail, matrix $E \in \mathbb{R}^{\left(n_{f} \times n_{f}\right)}$ describes the effects of the domestic fiscal policy on the domestic real output gaps (diagonal elements) and those of the foreign fiscal policies on the domestic real output gaps (off-diagonal elements), i.e. fiscal spillovers. Similarly, matrix $B \in \mathbb{R}^{\left(n_{f}+n_{b}\right) \times n_{f}}$ describes the effects of fiscal policy on the price and exchange-rate dynamics. Matrices $D \in \mathbb{R}^{n_{f} \times\left(n_{f}+n_{b}\right)}$ and $A \in \mathbb{R}^{\left(n_{f}+n_{b}\right) \times\left(n_{f}+n_{b}\right)}$ indicate the effects of price levels and exchange rates on the domestic real output gaps and price and exchange-rate dynamics, respectively. Matrices $M \in \mathbb{R}^{\left(n_{f} \times n_{b}\right)}$ and $N \in \mathbb{R}^{\left(n_{f}+n_{b}\right) \times n_{b}}$ are the semi-elasticities of the nominal interest rates on real output gaps and price and exchange-rate dynamics, respectively.

\section{General aspects of accession}

The question arises what are the effects of the accession of additional countries to the MU and under which conditions such an accession is beneficial for the acceding countries and for existing members. The correct way to measure and evaluate accession effects (on macroeconomic adjustment, policy formation and cooperation, and the resulting welfare losses) is by comparing identical situations (in terms of

\footnotetext{
${ }^{8}$ See www.ua.ac.be/joseph.plasmans.

${ }^{9}$ The dimension of all vectors but $i(t)$ and $e(t)$ is $n_{f}$. The dimension of the vectors $i(t)$ and $e(t)$ is equal to the number of existing central banks $n_{b}$.
} 
shocks, structures, and preferences) under two scenarios: (i) without accession (called 'pre-accession') and (ii) with accession (called 'post-accession'). The net effects can then be attributed solely to the accession. Calculating welfare gains/losses and graphs of the situation without and with enlargement immediately provides the accession effects and this can be done, not only for the acceding countries, but also for the countries that were already participating in the MU and for the countries that do not accede at all.

We would expect that outsiders would like to accede if they are better off in the MU than staying outside. Similarly, we could expect that current member states agree to an MU enlargement if it makes them better off. Enlarging the MU when countries are asymmetric is likely to make it more heterogeneous. To study this feature and assess its consequences, we need -apart from a symmetric baseline for reference purposes- also cases where the acceding countries are different from the existing members, e.g. in shocks, structure, preferences, etc.

These important issues can be addressed in a relatively straightforward manner in our approach. In our model, acceding the MU implies that for an accession country: (i) there are no longer exchange rate adjustments possible vis-à-vis countries that already participate in the MU; (ii) its monetary policy is now set by the common $\mathrm{CB}$, the monetary policy of which may not be optimal for the acceding country because (a) it targets aggregate MU output and average inflation and (b) it may have different preferences as reflected in the values of $\alpha_{U}^{M}, \beta_{U}^{M}$, and $\chi_{U}^{M}$; (iii) participating in the MU could require that fiscal flexibility is stronger restrained because of the necessary adoption of fiscal-stringency measures like the SGP; this would imply a higher value of $\chi_{j}$ when country $j$ enters the MU; (iv) participation changes the strategic settings in the game and the possibilities for cooperation of policies for both acceding countries and existing member states.

For the common $\mathrm{CB}$, the accession of additional countries implies that: (i) there is a redefinition of the aggregate target variables; this by itself may already induce changes in optimal policymaking; (ii) its preferences may change if the acceding countries have different preferences as reflected in the values of $\alpha_{j}, \beta_{j}$, and $\chi_{j}$; this will affect policymaking; (iii) the strategic configurations (coalition formation process) in which the common $\mathrm{CB}$ operates have changed: the number of fiscal players in the MU increases and the number of outside monetary and fiscal players decreases. The adjustment dynamics from exchange-rate adjustment are changed.

For the (fiscal players of ) existing member countries, the accession implies: (i) changes in the policy reactions of the acceding countries and the common CB because of the reasons given above; (ii) the strategic configurations (coalition formation process) in which they operate have changed: the number of other fiscal players in the MU increases, while the number of outside monetary and fiscal players decreases.

Assuming that the economic structure is not affected by acceding the MU, we can determine the welfare effects of accession for (i) the acceding countries, (ii) the existing members by comparing losses under the no-accession scenario and the accession scenario, assuming a similar shock scenario. Incentive compatibility of accession would imply that both the acceding country and the existing member countries would not lose from the accession.

Given all the effects listed above it is, therefore, even in our highly-stylized model, by no means clear under which conditions the accession is likely to occur. 
The loss of exchange-rate and interest-rate flexibility is likely to entail negative costs for the acceding country, as does the possible increase in fiscal conservatism stemming from SGP-alike requirements. On the other hand, the change in the institutional settings, as reflected in the enhanced strategic position and coalition formation possibilities, may benefit the accession countries. The numerical analysis in the next section will elaborate on these insights about the net effects of accession.

\section{Numerical solutions of the model}

\subsection{General setup}

Our analysis considers a setting of 5 countries. Country 3 aims to enter an existing MU made of countries 1 and 2. At the pre-accession stage, there are 5 fiscal authorities (denoted as $C 1, \ldots, C 5$ ) and 4 monetary authorities (denoted as $C B, C B 3$, $C B 4, C B 5)$. At the post-accession stage the MU consists of $C 1, C 2$ and $C 3, C B 3$ ceases to exist and $C B$ takes over the monetary policy management in $C 3$.

Out of all possible coalition structures $(\mathrm{CSs}) \pi_{\mathrm{i}}$, which represent different cooperative arrangements between groups of players, we choose $37 \mathrm{CSs}$ at the preaccession stage and $27 \mathrm{CSs}$ at the post-accession stage. The first three CSs and the last two of both pre- and post-accession stages are reported as they are interesting reference points for comparison. In $\pi_{1}-\pi_{3}$, players $C 5$ and $C B 5$ play as singletons. However, in all the other CSs, but $\pi_{36}$ and $\pi_{37}$, they play as a full national coalition $\{C 5, C B 5\}$. Being in a coalition means that players are no more self-oriented but maximize their joint welfare.

Often one can find a natural correspondence between certain CSs before and after accession. The basic difference consists in taking over the activities of CB3 by the $\mathrm{CB}$ of the MU upon accession (at the post-accession stage $C B 3$ ceases to exist). From now on, we will refer to the $i^{\text {th }}$ CS by $\pi_{\mathrm{i}}$, where $i=1, \ldots, 64$, Table 1 .

We consider three different scenarios:

1. The benchmark scenario with a symmetric economic structure $\left(s c_{1}\right)$ - the $\mathrm{MU}$ consists of two countries, $C 1$ and $C 2$, while there is (only) one accession country, C3, one non-accession country, C4, and an additional country, C5. All countries are assumed to be symmetric in the structural and preference parameters and sizes. However, preferences of fiscal players are asymmetric w.r.t. preferences of central banks. The following set of parameters underlies this baseline case: $\gamma_{j^{b}}=0.2, \eta_{j^{b}}=0.75, \rho_{j^{b} \ell}=0.1, \delta_{j^{b} \ell}=0.1, \zeta_{j^{b}}=0.25, \varsigma_{j^{b} \ell}=0.1$, $\alpha_{j^{b}}=0.2, \beta_{j^{b}}=0.4, \chi_{j^{b}}=\chi_{U}^{M}=\chi_{j^{b}}^{M}=0.4, \alpha_{U}^{M}=\alpha_{j^{b}}^{M}=0.4, \beta_{U}^{M}=\beta_{j^{b}}^{M}=0.2$, $\omega_{j^{b}}=0.5, \theta=0.10 .^{10}$

\footnotetext{
${ }^{10}$ This parameterization is based on various empirical studies for the euro area. They suggest that the interest rate semi-elasticity of output $\left(\gamma_{\mathrm{i}}\right)$ lies in the range 0.1 to 0.3 (e.g. Angeloni et al. (2002) find a value of 0.19 ) and the other spillovers originate from the instantaneous multiplier of fiscal policy $\left(\eta_{i}\right)$ lying between 0.5 and 1 (European Commission (2001) uses a value of 0.5 in its model), the competitiveness effect $\left(\delta_{i j}\right)$ and the elasticity w.r.t. the foreign output gap $\left(\rho_{i j}\right)$, which are somewhere around 0.1 and 0.3 , respectively (Hooper et al. (1998)). Considerable evidence also exists for the property that the output-gap elasticity in the Phillips curve $\left(\zeta_{i}\right)$ is relatively small (Smets (2000) estimates a value of 0.18 ) and that there is some effect from foreign inflation rates $\left(\varsigma_{i j}\right)$ (Laxton et al. (1998)).
} 
Table 1 Pre- and post- accession coalition structures

\begin{tabular}{|c|c|c|c|}
\hline \multicolumn{4}{|c|}{ Pre-accession coalition structures } \\
\hline$\pi_{1}$ & C1 C2 CB C3 CB3 C4 CB4 C5 CB5 & $\pi_{20}$ & $\begin{array}{l}(\mathrm{C} 1, \mathrm{C} 2, \mathrm{C} 3) \mathrm{CB} \text { CB3 }(\mathrm{C} 4, \mathrm{CB} 4) \\
(\mathrm{C} 5, \mathrm{CB} 5)\end{array}$ \\
\hline$\pi_{2}$ & $(\mathrm{C} 1, \mathrm{C} 2) \mathrm{CB}$ C3 CB3 C4 CB4 C5 CB5 & $\pi_{21}$ & $(\mathrm{C} 1, \mathrm{C} 3) \mathrm{C} 2 \mathrm{CB} \mathrm{CB} 3 \mathrm{C} 4 \mathrm{CB} 4(\mathrm{C} 5, \mathrm{CB} 5)$ \\
\hline$\pi_{3}$ & $(\mathrm{C} 1, \mathrm{C} 2, \mathrm{CB}) \mathrm{C} 3 \mathrm{CB} 3 \mathrm{C} 4 \mathrm{CB} 4 \mathrm{C} 5 \mathrm{CB} 5$ & $\pi_{22}$ & $\begin{array}{l}(\mathrm{C} 1, \mathrm{C} 3) \mathrm{C} 2 \mathrm{CB} \text { CB3 }(\mathrm{C} 4, \mathrm{CB} 4) \\
(\mathrm{C} 5, \mathrm{CB} 5)\end{array}$ \\
\hline$\pi_{4}$ & C1 C2 CB C3 CB3 C4 CB4 (C5,CB5) & $\pi_{23}$ & $(\mathrm{C} 2, \mathrm{C} 3) \mathrm{C} 1 \mathrm{CB}$ CB3 C4 CB4 (C5,CB5) \\
\hline$\pi_{5}$ & $\mathrm{C} 1 \mathrm{C} 2 \mathrm{CB}(\mathrm{C} 3, \mathrm{CB} 3) \mathrm{C} 4 \mathrm{CB} 4(\mathrm{C} 5, \mathrm{CB} 5)$ & $\pi_{24}$ & $\begin{array}{l}(\mathrm{C} 2, \mathrm{C} 3) \mathrm{C} 1 \mathrm{CB} \text { CB3 }(\mathrm{C} 4, \mathrm{CB} 4) \\
(\mathrm{C} 5, \mathrm{CB} 5)\end{array}$ \\
\hline$\pi_{6}$ & C1 C2 CB C3 CB3 $(\mathrm{C} 4, \mathrm{CB} 4)(\mathrm{C} 5, \mathrm{CB} 5)$ & $\pi_{25}$ & $(\mathrm{C} 1, \mathrm{C} 2, \mathrm{C} 4) \mathrm{CB}$ C3 CB3 CB4 $(\mathrm{C} 5, \mathrm{CB} 5)$ \\
\hline$\pi_{7}$ & $\mathrm{C} 1 \mathrm{C} 2 \mathrm{CB}(\mathrm{C} 3, \mathrm{CB} 3)(\mathrm{C} 4, \mathrm{CB} 4)(\mathrm{C} 5, \mathrm{CB} 5)$ & $\pi_{26}$ & $\begin{array}{l}(\mathrm{C} 1, \mathrm{C} 2, \mathrm{C} 4) \mathrm{CB}(\mathrm{C} 3, \mathrm{CB} 3) \mathrm{CB} 4 \\
(\mathrm{C} 5, \mathrm{CB} 5)\end{array}$ \\
\hline$\pi_{8}$ & $\mathrm{C} 1 \mathrm{C} 2 \mathrm{CB}(\mathrm{C} 3, \mathrm{C} 4) \mathrm{CB} 3 \mathrm{CB} 4(\mathrm{C} 5, \mathrm{CB} 5)$ & $\pi_{27}$ & $(\mathrm{C} 1, \mathrm{C} 4) \mathrm{C} 2$ CB C3 CB3 CB4 (C5,CB5) \\
\hline$\pi_{9}$ & $(\mathrm{C} 1, \mathrm{C} 2, \mathrm{CB}) \mathrm{C} 3 \mathrm{CB} 3 \mathrm{C} 4 \mathrm{CB} 4(\mathrm{C} 5, \mathrm{CB} 5)$ & $\pi_{28}$ & $(\mathrm{C} 1, \mathrm{C} 4) \mathrm{C} 2 \mathrm{CB}(\mathrm{C} 3, \mathrm{CB} 3) \mathrm{CB} 4(\mathrm{C} 5, \mathrm{CB} 5)$ \\
\hline$\pi_{10}$ & $(\mathrm{C} 1, \mathrm{C} 2, \mathrm{CB})(\mathrm{C} 3, \mathrm{CB} 3) \mathrm{C} 4 \mathrm{CB} 4(\mathrm{C} 5, \mathrm{CB} 5)$ & $\pi_{29}$ & $(\mathrm{C} 2, \mathrm{C} 4) \mathrm{C} 1 \mathrm{CB}$ C3 CB3 CB4 (C5,CB5) \\
\hline$\pi_{11}$ & $(\mathrm{C} 1, \mathrm{C} 2, \mathrm{CB}) \mathrm{C} 3 \mathrm{CB} 3(\mathrm{C} 4, \mathrm{CB} 4)(\mathrm{C} 5, \mathrm{CB} 5)$ & $\pi_{30}$ & $(\mathrm{C} 2, \mathrm{C} 4) \mathrm{C} 1 \mathrm{CB}(\mathrm{C} 3, \mathrm{CB} 3) \mathrm{CB} 4(\mathrm{C} 5, \mathrm{CB} 5)$ \\
\hline$\pi_{12}$ & $\begin{array}{l}(\mathrm{C} 1, \mathrm{C} 2, \mathrm{CB})(\mathrm{C} 3, \mathrm{CB} 3)(\mathrm{C} 4, \mathrm{CB} 4) \\
(\mathrm{C} 5, \mathrm{CB} 5)\end{array}$ & $\pi_{31}$ & $(\mathrm{C} 1, \mathrm{C} 2, \mathrm{C} 3, \mathrm{C} 4) \mathrm{CB}$ CB3 CB4 $(\mathrm{C} 5, \mathrm{CB} 5)$ \\
\hline$\pi_{13}$ & $(\mathrm{C} 1, \mathrm{C} 2, \mathrm{CB})(\mathrm{C} 3, \mathrm{C} 4) \mathrm{CB} 3 \mathrm{CB} 4(\mathrm{C} 5, \mathrm{CB} 5)$ & $\pi_{32}$ & $\begin{array}{l}(\mathrm{C} 1, \mathrm{C} 4)(\mathrm{C} 2, \mathrm{C} 3) \mathrm{CB} \text { CB3 CB} 4 \\
(\mathrm{C} 5, \mathrm{CB} 5)\end{array}$ \\
\hline$\pi_{14}$ & $(\mathrm{C} 1, \mathrm{C} 2) \mathrm{CB}$ C3 CB3 C4 CB4 (C5,CB5) & $\pi_{33}$ & $(\mathrm{C} 1, \mathrm{C} 3, \mathrm{C} 4) \mathrm{C} 2 \mathrm{CB}$ CB3 CB4 $(\mathrm{C} 5, \mathrm{CB} 5)$ \\
\hline$\pi_{15}$ & $(\mathrm{C} 1, \mathrm{C} 2) \mathrm{CB}(\mathrm{C} 3, \mathrm{CB} 3) \mathrm{C} 4 \mathrm{CB} 4(\mathrm{C} 5, \mathrm{CB} 5)$ & $\pi_{34}$ & $(\mathrm{C} 2, \mathrm{C} 3, \mathrm{C} 4) \mathrm{C} 1 \mathrm{CB}$ CB3 CB4 $(\mathrm{C} 5, \mathrm{CB} 5)$ \\
\hline$\pi_{16}$ & $(\mathrm{C} 1, \mathrm{C} 2) \mathrm{CB}$ C3 CB3 $(\mathrm{C} 4, \mathrm{CB} 4)(\mathrm{C} 5, \mathrm{CB} 5)$ & $\pi_{35}$ & $\begin{array}{l}(\mathrm{C} 1, \mathrm{C} 3)(\mathrm{C} 2, \mathrm{C} 4) \mathrm{CB} \text { CB3 CB} 4 \\
(\mathrm{C} 5, \mathrm{CB} 5)\end{array}$ \\
\hline$\pi_{17}$ & $(\mathrm{C} 1, \mathrm{C} 2) \mathrm{CB}(\mathrm{C} 3, \mathrm{CB} 3)(\mathrm{C} 4, \mathrm{CB} 4)(\mathrm{C} 5, \mathrm{CB} 5)$ & $\pi_{36}$ & $(\mathrm{C} 1, \mathrm{C} 2, \mathrm{C} 3, \mathrm{C} 4, \mathrm{C} 5) \mathrm{CB}$ CB3 CB4 CB5 \\
\hline$\pi_{18}$ & $(\mathrm{C} 1, \mathrm{C} 2) \mathrm{CB}(\mathrm{C} 3, \mathrm{C} 4) \mathrm{CB} 3 \mathrm{CB} 4(\mathrm{C} 5, \mathrm{CB} 5)$ & $\pi_{37}$ & $(\mathrm{C} 1, \mathrm{C} 2, \mathrm{CB}, \mathrm{C} 3, \mathrm{CB} 3, \mathrm{C} 4, \mathrm{CB} 4, \mathrm{C} 5, \mathrm{CB} 5)$ \\
\hline$\pi_{19}$ & $(\mathrm{C} 1, \mathrm{C} 2, \mathrm{C} 3) \mathrm{CB}$ CB3 C4 CB4 (C5,CB5) & & \\
\hline \multicolumn{4}{|c|}{ Post-accession coalition structures } \\
\hline$\pi_{38}$ & C1 C2 C3 CB C4 CB4 C5 CB5 & $\pi_{52}$ & $(\mathrm{C} 1, \mathrm{C} 3) \mathrm{C} 2 \mathrm{CB}(\mathrm{C} 4, \mathrm{CB} 4)(\mathrm{C} 5, \mathrm{CB} 5)$ \\
\hline$\pi_{39}$ & $(\mathrm{C} 1, \mathrm{C} 2) \mathrm{C} 3 \mathrm{CB}$ C4 CB4 C5 CB5 & $\pi_{53}$ & $(\mathrm{C} 1, \mathrm{C} 4) \mathrm{C} 2 \mathrm{C} 3 \mathrm{CB}$ CB4 $(\mathrm{C} 5, \mathrm{CB} 5)$ \\
\hline$\pi_{40}$ & $(\mathrm{C} 1, \mathrm{C} 2, \mathrm{C} 3, \mathrm{CB}) \mathrm{C} 4 \mathrm{CB} 4 \mathrm{C} 5 \mathrm{CB} 5$ & $\pi_{54}$ & $\mathrm{C} 1$ (C2 C4) C3 CB CB4 (C5, CB5) \\
\hline$\pi_{41}$ & C1 C2 C3 CB C4 CB4 (C5,CB5) & $\pi_{55}$ & $\mathrm{C} 1, \mathrm{C} 2(\mathrm{C} 3, \mathrm{C} 4) \mathrm{CB}$ CB4 $(\mathrm{C} 5, \mathrm{CB} 5)$ \\
\hline$\pi_{42}$ & C1 C2 C3 CB $(\mathrm{C} 4, \mathrm{CB} 4)(\mathrm{C} 5, \mathrm{CB} 5)$ & $\pi_{56}$ & $(\mathrm{C} 1, \mathrm{C} 2)(\mathrm{C} 3, \mathrm{C} 4) \mathrm{CB}$ CB4 $(\mathrm{C} 5, \mathrm{CB} 5)$ \\
\hline$\pi_{43}$ & $(\mathrm{C} 1, \mathrm{C} 2, \mathrm{C} 3, \mathrm{CB}) \mathrm{C} 4 \mathrm{CB} 4(\mathrm{C} 5, \mathrm{CB} 5)$ & $\pi_{57}$ & $(\mathrm{C} 1, \mathrm{C} 3)(\mathrm{C} 2, \mathrm{C} 4) \mathrm{CB}$ CB4 $(\mathrm{C} 5, \mathrm{CB} 5)$ \\
\hline$\pi_{44}$ & $(\mathrm{C} 1, \mathrm{C} 2, \mathrm{C} 3, \mathrm{CB})(\mathrm{C} 4, \mathrm{CB} 4)(\mathrm{C} 5, \mathrm{CB} 5)$ & $\pi_{58}$ & $(\mathrm{C} 1, \mathrm{C} 4)(\mathrm{C} 2, \mathrm{C} 3) \mathrm{CB} \mathrm{CB} 4(\mathrm{C} 5, \mathrm{CB} 5)$ \\
\hline$\pi_{45}$ & $(\mathrm{C} 1, \mathrm{C} 2, \mathrm{C} 3) \mathrm{CB}$ C4 CB4 (C5,CB5) & $\pi_{59}$ & $(\mathrm{C} 1, \mathrm{C} 2, \mathrm{C} 4) \mathrm{CB}$ C3 CB4 $(\mathrm{C} 5, \mathrm{CB} 5)$ \\
\hline$\pi_{46}$ & $(\mathrm{C} 1, \mathrm{C} 2, \mathrm{C} 3) \mathrm{CB}(\mathrm{C} 4, \mathrm{CB} 4)(\mathrm{C} 5, \mathrm{CB} 5)$ & $\pi_{60}$ & $(\mathrm{C} 1, \mathrm{C} 3, \mathrm{C} 4) \mathrm{CB}$ C2 CB4 (C5,CB5) \\
\hline$\pi_{47}$ & $(\mathrm{C} 1, \mathrm{C} 2) \mathrm{C} 3 \mathrm{CB}$ C4 CB4 (C5,CB5) & $\pi_{61}$ & $(\mathrm{C} 2, \mathrm{C} 3, \mathrm{C} 4) \mathrm{CB} \mathrm{C} 1 \mathrm{C} 3 \mathrm{CB} 4(\mathrm{C} 5, \mathrm{CB} 5)$ \\
\hline$\pi_{48}$ & $(\mathrm{C} 1, \mathrm{C} 2) \mathrm{C} 3 \mathrm{CB}(\mathrm{C} 4, \mathrm{CB} 4)(\mathrm{C} 5, \mathrm{CB} 5)$ & $\pi_{62}$ & $(\mathrm{C} 1, \mathrm{C} 2, \mathrm{C} 3, \mathrm{C} 4) \mathrm{CB}$ CB4 $(\mathrm{C} 5, \mathrm{CB} 5)$ \\
\hline$\pi_{49}$ & C1 (C2,C3) CB C4 CB4 (C5,CB5) & $\pi_{63}$ & $(\mathrm{C} 1, \mathrm{C} 2, \mathrm{C} 3, \mathrm{C} 4, \mathrm{C} 5) \mathrm{CB} \mathrm{CB} 4 \mathrm{CB} 5$ \\
\hline$\pi_{50}$ & $\mathrm{C} 1(\mathrm{C} 2, \mathrm{C} 3) \mathrm{CB}(\mathrm{C} 4, \mathrm{CB} 4)(\mathrm{C} 5, \mathrm{CB} 5)$ & $\pi_{64}$ & $(\mathrm{C} 1, \mathrm{C} 2, \mathrm{C} 3, \mathrm{CB}, \mathrm{C} 4, \mathrm{CB} 4, \mathrm{C} 5 \mathrm{CB} 5)$ \\
\hline$\pi_{51}$ & $(\mathrm{C} 1, \mathrm{C} 3) \mathrm{C} 2 \mathrm{CB}$ C4 CB4 $(\mathrm{C} 5, \mathrm{CB} 5)$ & & \\
\hline
\end{tabular}


2. An asymmetric structural scenario $\left(s c_{2}\right)$ - in this example, we consider a situation where the countries are marked by asymmetries in the economic structure and in policy preferences. Simplifying, these asymmetries may be interpreted in terms of the size of the country. ${ }^{11}$ In particular, we assume that, compared with the symmetric baseline scenario:

(i) $\mathrm{C} 1$ is two times bigger than $\mathrm{C} 2$ and the accession country $\mathrm{C} 3$ and of an equal size as $\mathrm{C} 4$ and $\mathrm{C} 5$. The detailed parameter values are reported in Appendix A. Because $\mathrm{C} 1$ and $\mathrm{C} 2$ have a different size, CB1 is more concerned with the economic performance in $\mathrm{C} 1$ than in $\mathrm{C} 2$, implying that countries' weights in CB1's loss function are asymmetric: $\omega_{1}=2 / 3, \omega_{2}=1 / 3$ before accession and $\omega_{1}=1 / 2, \omega_{2}=1 / 4, \omega_{3}=1 / 4$ after accession.

(ii) $\mathrm{C} 4$ has a less conservative central bank, $\alpha_{4}^{M}=0.2$ and $\beta_{4}^{M}=0.4$; hence, coincide with the preferences of the fiscal authorities in $\mathrm{C} 4$.

3. An asymmetric structural scenario with asymmetric bargaining power $\left(s c_{3}\right)$, where we add asymmetric bargaining power $\tau$ to the previous case. More specifically, $\mathrm{C} 1$ is assumed to have a two times higher bargaining power than $\mathrm{C} 2$ and $\mathrm{C} 3$ in both pre- and post-accession stages and the same bargaining power as $\mathrm{C} 4$, while $\mathrm{C} 4$ has a three times higher bargaining power than CB4. The exact definition of $\tau$ is provided in Appendix C. ${ }^{12}$

Note that scenario $s c_{3}$ is the most realistic one, since structural asymmetries are accompanied by corresponding bargaining power asymmetries (so that a larger country has a larger bargaining power).

Three different types of shocks are analyzed (shocks always occur at $\mathrm{t}=0$ in the form of initial innovations to the state variables): (i) a symmetric (negative) supply shock: $s_{0 S}^{P}=[0.01 ; 0.01 ; 0.01 ; 0.01 ; 0.01,0,0,0,0]^{T}$, (ii) an asymmetric (negative) supply shock that hits only $\mathrm{C} 3: s_{0 A}^{P}=[0 ; 0 ; 0.01 ; 0 ; 0 ; 0 ; 0 ; 0 ; 0]^{T}$, and (iii) an asymmetric exchange-rate shock that hits $\mathrm{C} 5: s_{0 E}^{P}=[0 ; 0 ; 0 ; 0 ; 0 ; 0 ; 0 ; 0 ; 0.01]^{T}$ in the pre-accession stage. In the post-accession stage, these shocks are defined as $s_{0 S}^{A}=[0.01 ; 0.01 ; 0.01 ; 0.01 ; 0.01 ; 0 ; 0 ; 0 ;]^{T}$, (ii) $s_{0 A}^{A}=[0 ; 0 ; 0.1 ; 0 ; 0 ; 0 ; 0 ; 0]^{T}$, and (iii) $s_{0 E}^{A}=[0 ; 0 ; 0 ; 0 ; 0 ; 0 ; 0 ; 0.1]^{T}$.

For clarity and in order to save space, we will characterize the pre- and postaccession scenarios by providing superscripts $P$ and $A$, respectively (i.e., $s c_{1}^{P}, s c_{2}^{P}$, $s c_{3}^{P}, s c_{1}^{A}, s c_{2}^{A}, s c_{3}^{A}$ ). Below we will present optimal losses for symmetric scenario $s c_{1}^{P}$ under symmetric price shock $s c_{0 S}^{P}$ for both pre- and post-accession stages. For brevity, in the case of other shocks/scenarios we report optimal losses only for one specific CS. The rest of the results is available on the internet. ${ }^{13}$

\footnotetext{
${ }^{11}$ Both small and big countries can be either relatively open or relatively closed. A relatively closed but big country may still affect other countries via direct spillover channels more than a relatively open but small country. Hence, the interpretation of our direct spillover parameters $\rho_{j^{b} \ell}, \delta_{j^{b} \ell}, \varsigma_{j^{b} \ell}$ is not straightforward. They represent the mixed effects of size and openness. To have a clear interpretation we may assume either that countries are of equal size and the value of a spillover parameter indicates openness or that countries differ in size but are equally open. In the latter case the value of a spillover parameter shows relative size of a country. In this paper we will follow this interpretation.

12 See www.ua.ac.be/joseph.plasmans.

13 See www.ua.ac.be/joseph.plasmans.
} 


\subsection{Pre-accession stage, symmetric model}

Table 5 in Appendix A reports (optimal) losses for a symmetric model in the preaccession stage under symmetric price shock $s_{0 \mathrm{~S}} .{ }^{14}$ Note that while looking for the social optimum CS(s), only CSs from $\pi_{4}$ to $\pi_{35}$ (in Table 5) and from $\pi_{41}$ to $\pi_{62}$ (in Table 6 in Appendix A) are taken into account.

The consequences of a symmetric shock in the symmetric model in the preaccession stage are found in Table 5. The differences in (optimal) losses between the different CSs are relatively small suggesting that policy coordination is of limited importance in the case of symmetric shocks and in the presence of symmetric countries. The differences between being inside or outside the MU are essentially negligible in all regimes. It is worth analyzing the fully non-cooperative regime $\pi_{1}$ in Table 5. Losses of $\mathrm{C} 1$ and $\mathrm{C} 2$ differ from those of C3,C4 and C5, in spite of the fact that all countries have symmetric economic structures and preference parameters. The similar effect is visible also in losses of CBs and is caused by the asymmetry in the interest rates. Simply, the insiders are subject to the common interest rate set by the $\mathrm{CB}$, while outsiders have their own national CBs. Moreover, notice that losses of countries are in general much lower than losses of CBs. It can indicate both that the magnitude of inflation caused by a shock is in general larger than the magnitude of the output gap and/or that the interest rate instrument is more used than the fiscal debt. $^{15}$

\subsection{Post-accession stage, symmetric model}

Table 6 presents players' losses at the post-accession stage for the symmetric baseline scenario in the case of a symmetric shock. These results can be directly compared to Table 5 for the pre-accession stage. Accession of C3 leads to only marginal changes in the case of symmetric shocks. As before, differences between CSs are small under symmetric shocks after accession, suggesting that in the case of symmetric shocks accession has no substantial effects, neither for the accession countries nor for the existing members.

\subsection{Asymmetries in economic structures and shocks}

For reasons of brevity we do not report all optimal losses for other cases. ${ }^{16}$ To give a flavour of shock consequences, model and bargaining-power asymmetries we list in Table 2 optimal losses for all the combinations of scenarios and shocks in two regimes: $\pi_{12}=[\mathrm{C} 1 \mathrm{C} 2 \mathrm{CB}|\mathrm{C} 3 \mathrm{CB} 3| \mathrm{C} 4 \mathrm{CB} 4 \mid \mathrm{C} 5 \mathrm{CB} 5]$ and $\pi_{44}=[\mathrm{C} 1 \mathrm{C} 2 \mathrm{C} 3 \mathrm{CB}|\mathrm{C} 4 \mathrm{CB} 4|$

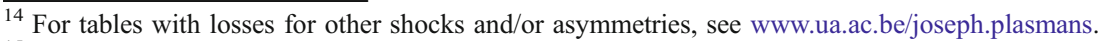

${ }^{15}$ Note the perfect anti-symmetry between preferences of countries and central banks w.r.t. inflation and output gap.

${ }^{16}$ I.e.: $\left(s c_{1}^{P}, s_{0 A}^{P}\right) ;\left(s c_{1}^{P}, s_{0 E}^{P}\right) ;\left(s c_{2}^{P}, s_{0 S}^{P}\right) ;\left(s c_{2}^{P}, s_{0 A}^{P}\right) ;\left(s c_{2}^{P}, s_{0 E}^{P}\right) ;\left(s c_{3}^{P}, s_{0 S}^{P}\right) ;\left(s c_{3}^{P}, s_{0 A}^{P}\right) ;\left(s c_{3}^{P}, s_{0 E}^{P}\right) ;\left(s c_{1}^{A}, s_{0 S}^{A}\right)$; $\left(s c_{1}^{A}, s_{0 A}^{A}\right) ;\left(s c_{1}^{A}, s_{0 E}^{A}\right) ;\left(s c_{2}^{A}, s_{0 s}^{A}\right) ;\left(s c_{2}^{A}, s_{0 A}^{A}\right) ;\left(s c_{2}^{A}, s_{0 E}^{A}\right) ;\left(s c_{3}^{A}, s_{0 S}^{A}\right) ;\left(s c_{3}^{A}, s_{0 A}^{A}\right) ;\left(s c_{3}^{A}, s_{0 E}^{A}\right)$.
} 
Table 2 Losses for CSs $\pi_{12}$ and $\pi_{44}$ in all combinations of scenarios and shocks

\begin{tabular}{|c|c|c|c|c|c|c|c|c|c|}
\hline \multirow{2}{*}{\multicolumn{2}{|c|}{$\begin{array}{l}\text { Sc: } \quad \text { Structural } \\
\text { Pre-accession stage }\end{array}$}} & \multicolumn{2}{|c|}{$\operatorname{Symmetry}\left(S C_{1}^{P / A}\right)$} & \multicolumn{3}{|c|}{$\begin{array}{l}\text { Structural } \\
\text { Asymmetry }\left(S C_{2}^{P / A}\right)\end{array}$} & \multicolumn{3}{|c|}{$\begin{array}{l}\text { Structural and bargaining power } \\
\text { asymmetry }\left(S C_{3}^{P / A}\right)\end{array}$} \\
\hline & & & & & & & & & \\
\hline Pl.IS. & $S_{0 S}^{P}$ & $S_{0 A}^{P}$ & $S_{0 E}^{P}$ & $S_{0 S}^{P}$ & $S_{0 A}^{P}$ & $S_{0 E}^{P}$ & $S_{0 S}^{P}$ & $S_{0 A}^{P}$ & $S_{0 E}^{P}$ \\
\hline $\mathrm{C} 1$ & 0.2480 & 0.1092 & 0.1081 & 0.2499 & 0.0511 & 0.1852 & 0.2483 & 0.0503 & 0.1823 \\
\hline $\mathrm{C} 2$ & 0.2480 & 0.1092 & 0.1081 & 0.2472 & 0.0374 & 54 & 0.2492 & 0.0431 & 0.1559 \\
\hline $\mathrm{CB}$ & 0.4921 & 0.1427 & 0.1375 & 0.4931 & 0.0631 & 2112 & 0.4934 & 0.0776 & 0.2589 \\
\hline $\mathrm{C} 3$ & 0.2481 & 2.4195 & 0.1287 & 0.2479 & 2.5014 & 0.1700 & 0.2481 & 2.4784 & 0.1848 \\
\hline CB3 & 0.4918 & 2.3501 & 0.1173 & 0.4929 & 2.6107 & 0.1734 & 0.4931 & 2.5531 & 0.2116 \\
\hline $\mathrm{C} 4$ & 0.2481 & 0.1301 & 0.1287 & 0.2463 & 0.0574 & & 0.2461 & 0.0353 & 0.1298 \\
\hline CB4 & 8 & & & & & & & & 0.3478 \\
\hline $\mathrm{C} 5$ & 0.2481 & 0.1301 & 0.0053 & 0.2492 & 0.0592 & 0.9548 & 0.2495 & 0.0646 & 0.9077 \\
\hline CB5 & 0.4918 & 0.1223 & 0.6367 & 0.4927 & 0.0554 & 1.4787 & 0.4929 & 0.0675 & 1.3885 \\
\hline WIX & $0.85 \%$ & $0.00 \%$ & $5.11 \%$ & $0.94 \%$ & $0.12 \%$ & $4.75 \%$ & $1.00 \%$ & $0.00 \%$ & $17.76 \%$ \\
\hline CFI & $0.49 \%$ & $13.77 \%$ & $30.69 \%$ & & $13.85 \%$ & $26.61 \%$ & $0.76 \%$ & $14.24 \%$ & $46.12 \%$ \\
\hline \multicolumn{10}{|c|}{ Post-accession stage } \\
\hline PI $\backslash S$ & $S_{0 S}^{A}$ & $S_{0 A}^{A}$ & $S_{0 E}^{A}$ & $S_{0 S}^{A}$ & $S_{0 A}^{A}$ & $S_{0 E}^{A}$ & $S_{0 S}^{A}$ & $S_{0 A}^{A}$ & $S_{0 E}^{A}$ \\
\hline $\mathrm{C} 1$ & 0.2483 & 1.0731 & 0.1027 & 0.2509 & 0.8656 & 0.1759 & 0.2484 & 0.5756 & 0.1654 \\
\hline $\mathrm{C} 2$ & 0.2483 & 1.0731 & 0.1027 & 0.2475 & 0.7113 & 39 & 0.2492 & 0.4753 & 0.1405 \\
\hline $\mathrm{C} 3$ & 0.2483 & 6.3947 & 0.1027 & & & & 0.2492 & 7.2718 & 0.1405 \\
\hline $\mathrm{CB}$ & 0.4923 & 0.1355 & 0.1642 & 0.4944 & 0.1726 & 0.2559 & 0.4947 & 0.0688 & 0.3172 \\
\hline $\mathrm{C} 4$ & 0.2480 & 0.1255 & 0.1304 & 0.2463 & 0.0618 & 0.2109 & 0.2462 & 0.0348 & 0.1269 \\
\hline CB4 & 0.4922 & 0.0954 & 0.1323 & 0.2518 & 0.0350 & 0.2271 & 0.2519 & 0.1029 & 0.3923 \\
\hline $\mathrm{C} 5$ & 0.2480 & 0.1255 & 2.0028 & 0.2493 & 0.0627 & 1.9491 & 0.2496 & 0.0609 & 1.9021 \\
\hline CB5 & 0.4922 & 0.0954 & 1.5913 & 0.4940 & 0.0362 & 1.4295 & 0.4942 & 0.0722 & 1.3332 \\
\hline WIX & $0.91 \%$ & $0.00 \%$ & $\%$ & $\%$ & $0.06 \%$ & $0.00 \%$ & $8 \%$ & $0.03 \%$ & $9.26 \%$ \\
\hline CFI & $0.61 \%$ & $11.08 \%$ & $40.83 \%$ & $0.95 \%$ & $20.88 \%$ & $38.17 \%$ & $1.01 \%$ & $5.08 \%$ & $60.30 \%$ \\
\hline
\end{tabular}

C5CB5]. These two particular CSs were chosen because of two reasons. First, they can be directly compared and second, they are characterized by a high degree of players' cooperation, which will show the effects of the bargaining power asymmetries in $s c_{3}^{P}$ and $s c_{3}^{A}$.

First, analyze symmetric scenario $s c_{1}^{P}$ under asymmetric shocks $s_{0 S}^{P}$ and $s_{0 E}^{P}$. Clearly, when an asymmetric price shock hits C3 outcomes are much different from the symmetric shock case. The asymmetry of the shock makes C3 to be less competitive; hence, this economy features by far highest losses and all the other countries are influenced only via spillovers and externalities. The exchange rate shock to C5 means that the currency of this country depreciates which raises its competitiveness vis-à-vis the other economies.

At the same time it increases inflation in $C 5$ and reduces inflation in the other countries; this pass-through effect therefore will start to mitigate the initial competitiveness effects. The effects are felt much stronger in $C 5$ as the exchange rate shock implies that it initially depreciates against all other countries, whereas 
from the perspective of the other countries, they only initially appreciate $v i s-\grave{a}-v i s$ C5.

The effects from C3's accession to the MU are found from a comparison of the upper (pre-accession, $s c^{\mathrm{P}}$ ) and lower (post-accession, $s c^{\mathrm{A}}$ ) parts of Table 2. In case of the symmetric shock, the effects are rather small. The most striking are the effects of an asymmetric price shock that hits $C 3$. Before and after the accession losses of this country are very high compared to losses of other players. Moreover, as pointed out in previous tables, the costs incurred by $C 3$ at the pre-accession stage is much lower than those at the post-accession stage. It suggests that the study of a symmetric shock is a good starting point but the real issue at stake are asymmetric shocks since their influence is the highest. Hence, in our model lack of the exchange rate adjustment (what also means sharing a common interest rate in an MU) is a big burden to the economy hit by an asymmetric shock. We can, therefore, state that if the structure of C3's economy differs more from the economic structure of the existing MU countries and there is a higher risk of an asymmetric shock, it becomes less likely that the MU will be enlarged and it is in the interest of both current and prospective members of the MU that the enlargement is postponed until a larger degree of economic convergence is achieved. These findings are in line with conclusions of the OCA theory.

Comparing $\left(s c_{2}^{P / A}, s_{0 S}^{P / A}\right)$ to $\left(s c_{1}^{P / A}, s_{0 S}^{P / A}\right)$ we see the effects of the model asymmetries in case of a symmetric shock. Differences are limited both in the preand post accession cases. The large country $C 1$ has higher losses than the smaller country $C 2$ whereas in the symmetric scenario losses were identical. $C 3$ and $C 4$ also acquire lower losses than in the benchmark. The importance of model asymmetries is more profound in case of asymmetric shocks as a comparison of $\left(s c_{2}^{P / A}, s_{0 A}^{P / A}\right)$ to $\left(s c_{1}^{P / A}, s_{0 A}^{P / A}\right)$ suggests. Similarly, the asymmetries have substantial consequences in case of the exchange rate shock as $\left(s c_{2}^{P / A}, s_{0 E}^{P / A}\right)$ to $\left(s c_{1}^{P / A}, s_{0 E}^{P / A}\right)$. Note also, that in $\mathrm{sc}_{1}$ - with the exception of $C 3, C B 3, C 5$ and $C B 5$ - the exchange rate shock leads to rather similar effects as the asymmetric shock. ${ }^{17}$

\subsection{Effects of accession}

To get a better insight from the discussion of all scenarios we use some simple statistical methods. It is interesting to see what are for a particular player the average (optimal) losses over all CSs. More formally, the average value $\widehat{J}_{i}$ is defined as follows. For $\Pi^{\mathrm{MU}}:=\left\{\pi_{4}, \pi_{5}, \ldots, \pi_{35}\right\}$ in the pre-accession stage $\widehat{\widehat{J}}_{i}:=\frac{1}{32} \sum_{s=4}^{35} \widehat{J}_{i}\left(\pi_{s}\right)$ and for $\Pi^{\mathrm{MU}}:=\left\{\pi_{41}, \pi_{42}, \ldots, \pi_{62}\right\}$ in the post-accession stage $\widehat{\widehat{J}}_{i}:=\frac{1}{22} \sum_{s=41}^{62} \widehat{J}_{i}\left(\pi_{s}\right)$ where $\widehat{J}_{i}\left(\pi_{s}\right)$ is an optimal loss of a player $i$ in CS $\pi_{\mathrm{s}}$. We compute $\widehat{J}_{i}$ for every player $i=C 1, C 2$, ..., $C B 5$ in every shock/scenario combination in the pre-accession and post-accession stage. These results are reported in Table 3.

Since Table 3 reports average (optimal) losses, similarly to Tables 5 and 6, it shows at hand many characteristics of our model. However, now it aggregates possible effects of different coordination regimes. Obviously, in $\left(s c_{1}^{P}, s_{0 S}^{P}\right)$ losses of $C 1$ and $C 2$ and $C 3$ and $C 4$ are symmetric since economic spillovers and resulting

\footnotetext{
${ }^{17}$ See Plasmans et al. (2006) for an adequate interpretation of the welfare index WIX and the coalition formation index CFI in Table 2.
} 
Table 3 Average value of losses in pre- and post-accession cases

\begin{tabular}{|c|c|c|c|c|c|c|c|c|c|}
\hline \multirow{2}{*}{\multicolumn{2}{|c|}{$\begin{array}{l}\text { Sc: } \quad \text { Structural } \\
\text { Pre-accession stage }\end{array}$}} & \multicolumn{2}{|c|}{$\operatorname{Symmetry}\left(S C_{1}^{P / A}\right)$} & \multicolumn{3}{|c|}{$\begin{array}{l}\text { Structural } \\
\text { Asymmetry }\left(S C_{2}^{P / A}\right)\end{array}$} & \multicolumn{3}{|c|}{$\begin{array}{l}\text { Structural and bargaining power } \\
\text { asymmetry }\left(S C_{3}^{P / A}\right)\end{array}$} \\
\hline & & & & \multirow{2}{*}{\multicolumn{2}{|c|}{$S_{0 S}^{P} \quad S_{0 A}^{P}$}} & \multirow[b]{2}{*}{$S_{0 E}^{P}$} & \multirow{3}{*}{$\begin{array}{l}S_{0 S}^{P} \\
\quad 0.2475\end{array}$} & \multirow{3}{*}{$\begin{array}{l}S_{0 A}^{P} \\
\quad 0.0830\end{array}$} & \multirow{3}{*}{$\begin{array}{l}S_{0 E}^{P} \\
\quad 0.2670\end{array}$} \\
\hline Pl.IS. & $S_{0 S}^{P}$ & $S_{0 A}^{P}$ & $S_{0 E}^{P}$ & & & & & & \\
\hline $\mathrm{C} 1$ & 0.2466 & 0.1694 & 0.1553 & & & & & & \\
\hline $\mathrm{C} 2$ & 466 & 0.1694 & 0.1553 & & & & & 0.0704 & 0.2254 \\
\hline CB & P & 0. & 0. & & & & & & 0.1429 \\
\hline $\mathrm{C} 3$ & & & & & & & & & \\
\hline CB3 & & & & & & & & & \\
\hline $\mathrm{C} 4$ & & & & & & & & & \\
\hline CB4 & 0.4885 & 0 & 0 & & & & & 82 & 02 \\
\hline $\mathrm{C} 5$ & & 0.1272 & & & & & & & 1.9230 \\
\hline CE & 4873 & 0.1106 & 1.7837 & 0.4877 & 0.0580 & 1.6183 & 0.4878 & 0.0573 & 1.5951 \\
\hline
\end{tabular}

Post-accession stage

\begin{tabular}{lllllllllll} 
P1.IS. & $S_{0 S}^{A}$ & \multicolumn{2}{l}{$S_{0 A}^{A}$} & \multicolumn{2}{l}{$S_{0 E}^{A}$} & \multicolumn{2}{l}{$S_{0 S}^{A}$} & \multicolumn{2}{l}{$S_{0 A}^{A}$} & \multicolumn{2}{l}{$S_{0 E}^{A}$} & \multicolumn{2}{l}{$S_{0 S}^{A}$} & \multicolumn{2}{l}{$S_{0 A}^{A}$} & \multicolumn{2}{l}{$S_{0 E}^{A}$} \\
$\mathrm{C} 1$ & 0.2464 & 0.9575 & 0.1591 & 0.2478 & 0.6197 & 0.2735 & 0.2474 & 0.5483 & 0.2746 \\
$\mathrm{C} 2$ & 0.2464 & 0.9575 & 0.1591 & 0.2471 & 0.4900 & 0.2187 & 0.2473 & 0.4563 & 0.2316 \\
$\mathrm{C} 3$ & 0.2464 & 6.8494 & 0.1591 & 0.2471 & 7.3495 & 0.2187 & 0.2473 & 7.4667 & 0.2316 \\
$\mathrm{CB}$ & 0.4893 & 0.1116 & 0.0827 & 0.4895 & 0.0729 & 0.1304 & 0.4896 & 0.0670 & 0.1368 \\
$\mathrm{C} 4$ & 0.2466 & 0.1826 & 0.1522 & 0.2458 & 0.0921 & 0.2179 & 0.2456 & 0.0598 & 0.1947 \\
$\mathrm{CB} 4$ & 0.4889 & 0.1188 & 0.0814 & 0.2453 & 0.0975 & 0.1588 & 0.2454 & 0.0872 & 0.1955 \\
$\mathrm{C} 5$ & 0.2484 & 0.1267 & 2.0030 & 0.2495 & 0.0635 & 1.9408 & 0.2495 & 0.0596 & 1.9253 \\
$\mathrm{CB} 5$ & 0.4876 & 0.1180 & 1.8015 & 0.4877 & 0.0711 & 1.6370 & 0.4878 & 0.0639 & 1.6150 \\
\hline
\end{tabular}

economic externalities influence them symmetrically. Naturally, this symmetry breaks up under the asymmetric shocks $s_{0 S}^{P}$ and $s_{0 E}^{P}$ and in the asymmetric scenarios $s c_{2}^{P}$ and $s c_{3}^{P}$. The same holds in the post-accession stage.

In Table 3 we clearly see the differences caused by asymmetries of the model. Comparing $s c_{2}^{P / A}$ to $s c_{1}^{P / A}$ and $s c_{3}^{P / A}$ to $s c_{2}^{P / A}$ we see that structural asymmetries have the larger impact on players' losses than bargaining power asymmetries. This result is not far from reality. The adjustment process after a shock is mainly driven by economic spillovers since both monetary and fiscal authorities have only limited influence on economic systems. When a shock occurs they can only partially control economies. Hence, even an almost complete lack of bargaining power in any coalition is not likely to increase losses substantially as, to a large extent, the economic system returns to balance by itself.

The average losses for $\left(s c_{1}^{P}, s_{0 s}^{P}\right)$ can be also compared with losses obtained in the non-cooperative regime $\pi_{4}$ in $s c_{1}^{P}$ (Table 5). This shows that on average all the fiscal players lose from coordination compared to the non-cooperative regime. From this, it could be argued, that if it is completely unclear which CS will be actually played after the coordination process, then all the fiscal players would not enter to any negotiations at all. They would prefer to play non-cooperatively since the expected 
loss from coordination is higher. However, this argument does not hold for any other combination of scenarios and shocks, i.e. expected loss from coordination for some players is lower than the (optimal) loss in the non-cooperative regime. The conclusion is that under these conditions players would support the existence of some coordination mechanism as their expected loss from any form of cooperation is lower than from a non-cooperative playing. ${ }^{18}$

To analyze effects of accession we will compute the difference between post- and pre-accession losses for each player, i.e.: $\Delta \mathfrak{£}_{i}=\widehat{J}_{i}^{(A)}-\widehat{J}_{i}^{(P)}$. Hence, the upper part of Table 4 is obtained by subtracting the upper part from the lower part of Table 3 after deleting $C B 3$.

Positive values in the upper part of Table 4 mean that for a particular player the accession is not (on average!) profitable. Hence, it comes out that on average accession is rather not profitable for the fiscal insiders under asymmetric shocks. Only in the case of a symmetric shock for $s c_{1}$ and $s c_{3}$ they both gain on average. In all combinations of scenarios and asymmetric shocks they lose. Moreover, note that these average losses from enlargement are in general much higher than feasible profits. The accession country $C 3$ gains from entering the MU only in the case of a symmetric shock, however, in all the three scenarios. The enlargement is on average profitable for all three directly involved fiscal players together only in $\left(s c_{1}, s_{O S}\right)$ and $\left(s c_{3}, s_{O S}\right)$. This suggests that actually, when structural/shock asymmetries are present, it would be very difficult in our model to reach an agreement on an MU enlargement, since, usually, such a decision should be taken unanimously.

Note that by far the highest increase in the average loss is faced by countries of the enlarged MU in the case of an asymmetric price shock. This happens with no exception for all 3 scenarios and certainly calls for further investigation. Therefore, we compute for each player (except $C B 3$ ) the difference between the minimal losses in the post-accession stage $\left(\pi_{42}\right.$ to $\left.\pi_{59}\right)$ and maximal losses in the pre-accession stage $\left(\pi_{4}\right.$ to $\left.\pi_{35}\right)$. More formally, we use the following formula to obtain the values in the middle part of Table 4:

$$
\Delta \widehat{\mathfrak{E}}_{i}=\frac{\widehat{J}_{i}^{\min (A)}-\widehat{J}_{i}^{\max (P)}}{\widehat{J}_{i}^{\max (P)}} \times 100
$$

where $\widehat{J}_{i}^{\min (A)}=\min _{\pi_{41-62}} \widehat{J}_{i}$ and $\widehat{J}_{i}^{\max (P)}=\max _{\pi_{4}-35} \widehat{J}_{i}$. Note that $\widehat{J}_{i}$ is policymaker $i$ 's optimal loss in a particular coalition structure. $\Delta \widehat{\mathfrak{E}}_{i}$ is in percentages and is computed for all three scenarios and shocks. All the negative numbers tell that there exists a post-accession CS in which the loss for the particular player is lower than the maximum of all losses that this player may incur in the pre-accession CSs. More formally: $\widehat{J}_{i}^{\min (A)}<\widehat{J}_{i}^{\max (P)}$. The result is ambiguous in these cases and requires further investigation. The only conclusion that can be drawn, is the following: for

\footnotetext{
${ }^{18}$ Of course, players can block an existence of a coordination mechanism hoping that they will (possibly) coordinate informally in a subgroup and free ride, when other players will pursue non-cooperative strategies. Such a situation is, in a way, contradictory to our assumption of perfect information, since due to spillovers/externalities every form of cooperation would be immediately noticed by other players.
} 


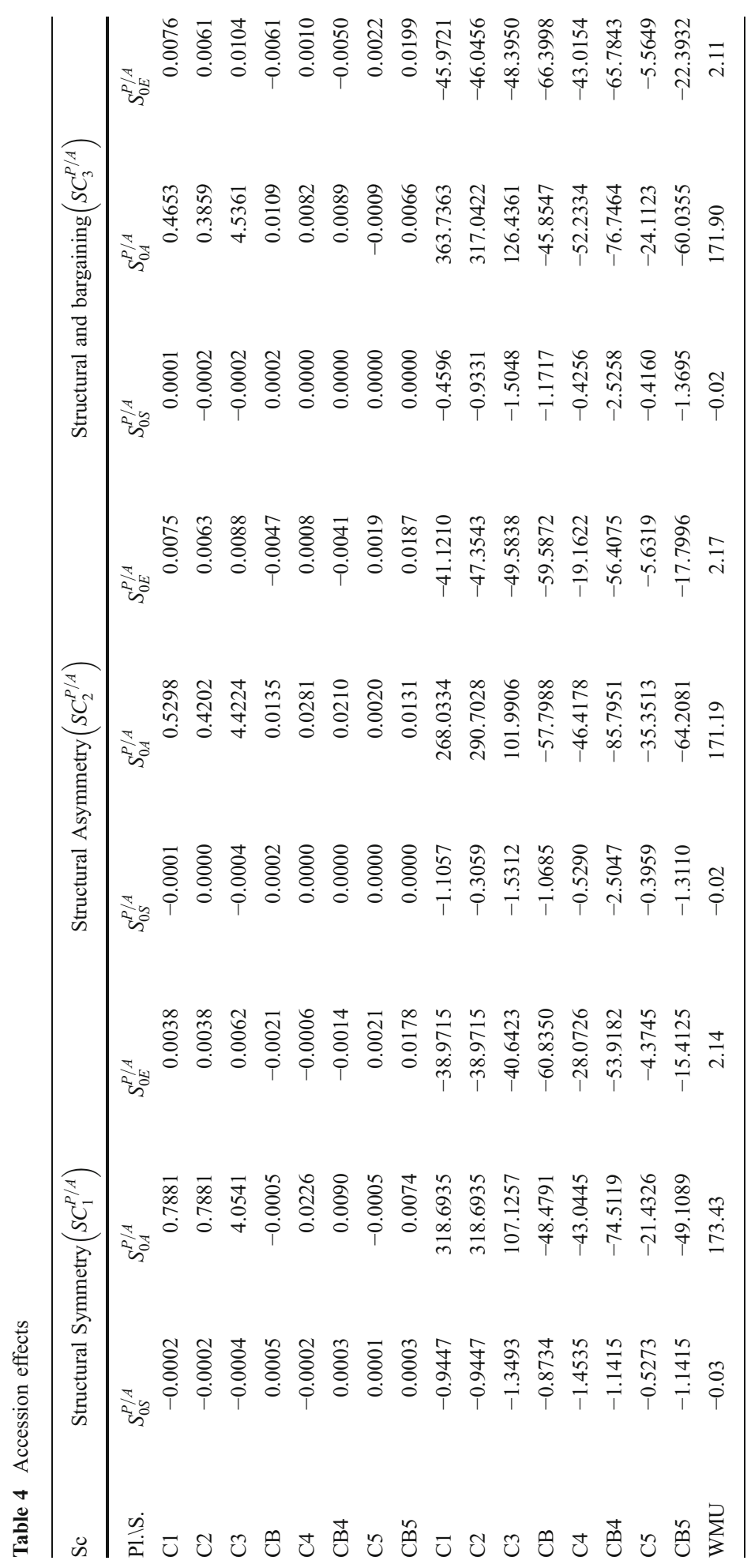


these types of shocks and scenarios we cannot exclude the possibility that gains from enlargement can be found when particular CSs before and after accession are considered.

However, in the case of an asymmetric price shock that hits accession country $C 3$, in all three scenarios, all countries of the enlarged MU, have increased losses in every possible coalition structure. So, always: $\widehat{J}_{i}^{\min (A)}>\widehat{J}_{i}^{\max (P)}$ for $i=C 1, C 2, C 3$. The enlargement cannot be profitable for any of the fiscal players in the case of an asymmetric price shock. Even, in the presence of a very effective coordination scheme, there is no CS that could assure gains for $C 1, C 2$ and $C 3$ after enlargement. This confirms our conclusion, that when there is a high risk of an asymmetric price shock in the accession country, the enlargement is unprofitable. Moreover, no coordination mechanism can make it profitable. This result obtained here using a framework with an extensive game- theoretic background is in line with results of the basic OCA analysis which lacks any game-theoretic considerations.

The question arises what the effect of enlargement will be on the total loss of the enlarged MU, defined as: $\mathrm{J}_{\mathrm{MU}} \equiv \mathrm{J}_{\mathrm{C} 1}+\mathrm{J}_{\mathrm{C} 2}+\mathrm{J}_{\mathrm{C} 3}+\mathrm{J}_{\mathrm{CB}}$. The last line of Table 4 presents the percentage change in the average value of $\mathrm{J}_{\mathrm{MU}}$ with regard to the pre-accession stage. $\mathrm{J}_{\mathrm{MU}}$ is positive in 6 cases, and negative in 3 cases. Moreover, increases of average losses are in general much higher than decreases; hence, we may conclude that the enlargement is rather not profitable also from the point of view of the MU joint welfare.

\section{Conclusion}

We find that the net effects of accession depend in particular on three factors: (i) the regime of policy coordination in place before and after accession; (ii) the type of macroeconomic shock and its degree of symmetry across countries; (iii) the degree of symmetry between countries in economic structure, sizes of countries and their policy preferences.

The main insights from our analyses can be summarized as follows: (i) Enlargement is likely to be unprofitable with increasing asymmetries in economic structures and economic shocks. (ii) Our findings stress the importance of an asymmetric shock. In our setting and in all the examples it emerges that if an asymmetric price shock occurs in the accession country it is never profitable to enlarge the MU. What is more, the differences in losses between the pre-accession stage and the post-accession stage are so high that it will be difficult to design a transfer system to compensate for a worse situation of some countries.

At the end some important limitations of our approach should be mentioned. First, in solving linear-quadratic differential games we assume open-loop information structure, i.e. all the control decisions are made at the beginning of the planning period and cannot be changed thereafter. Second, we assume a complete lack of uncertainty.

Some further issues call for further research. For instance, different types of shocks could be studied to further strengthen the obtained results. For example, it seems interesting to evaluate the effects of an exchange rate shock that hits the MU as a whole. If such a shock happens, is $C 3$ better off in the pre-accession stage than in the post-accession stage? If, in such a case, being in an MU is more profitable, the issue of accession will be concerned with a trade-off between the vulnerability to asymmetric price shocks and asymmetric exchange rate shocks. 


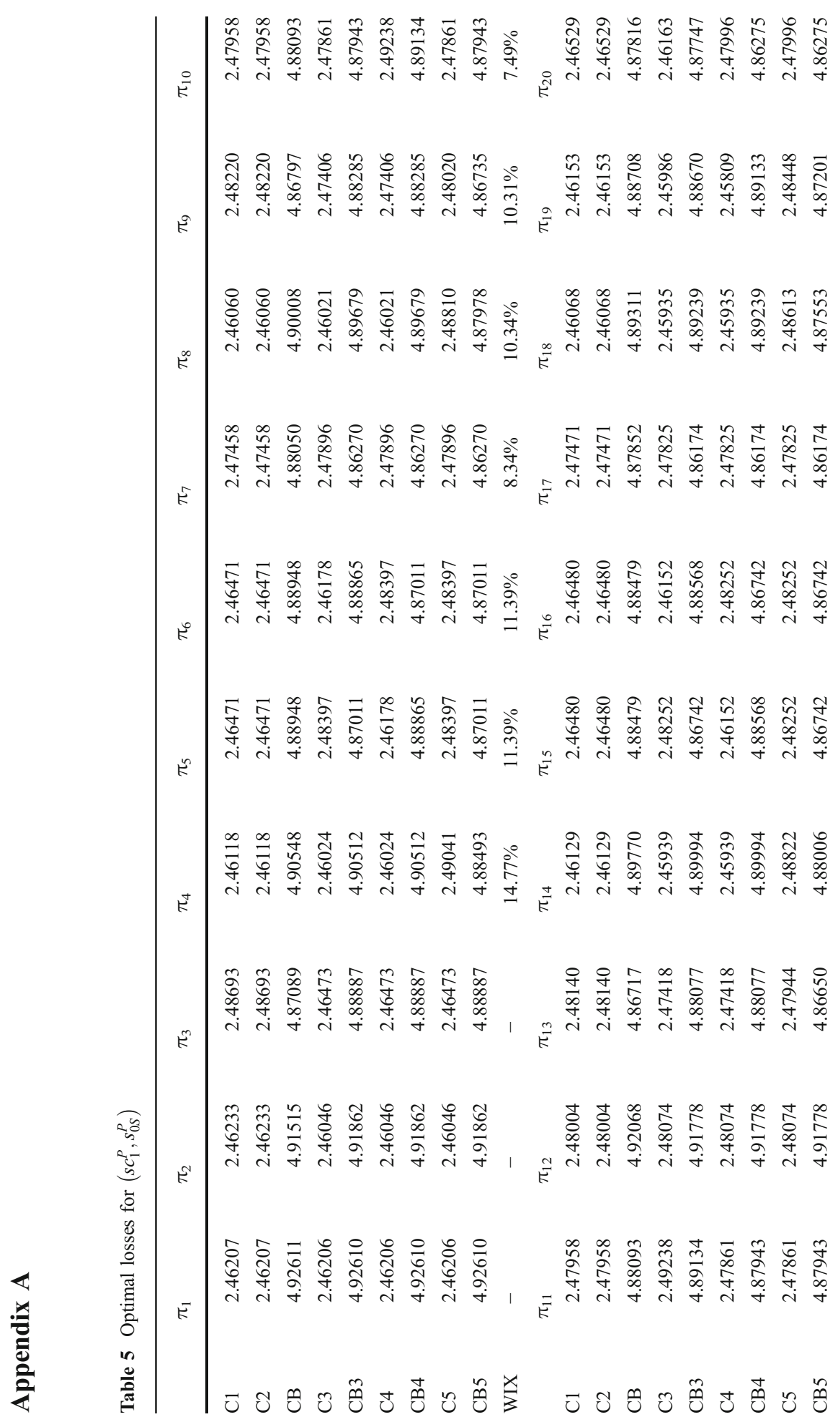




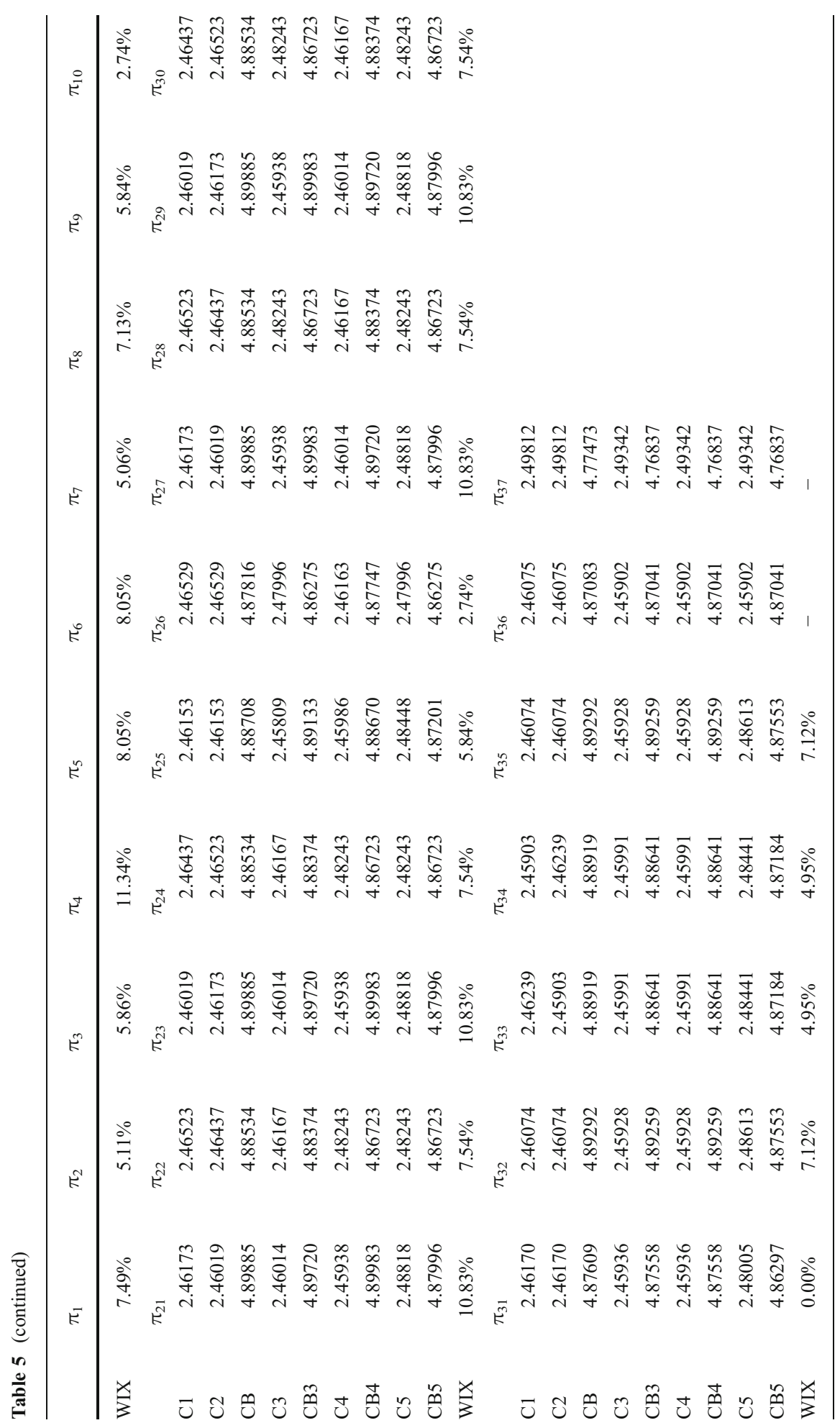


Table 6 Optimal losses for $\left(s c_{1}^{A}, s_{0 S}^{A}\right)$

\begin{tabular}{|c|c|c|c|c|c|c|c|c|c|}
\hline & $\pi_{38}$ & $\pi_{39}$ & $\pi_{40}$ & $\pi_{41}$ & $\pi_{42}$ & $\pi_{43}$ & $\pi_{44}$ & $\pi_{45}$ & $\pi_{46}$ \\
\hline $\mathrm{C} 1$ & 2.46207 & 2.46242 & 2.48564 & 2.46105 & 2.46458 & 2.48263 & 2.48274 & 2.46121 & 2.46501 \\
\hline $\mathrm{C} 2$ & 2.46207 & 2.46242 & 2.48564 & 2.46105 & 2.46458 & 2.48263 & 2.48274 & 2.46121 & 2.46501 \\
\hline $\mathrm{C} 3$ & 2.46207 & 2.46019 & 2.48564 & 2.46105 & 2.46458 & 2.48263 & 2.48274 & 2.46121 & 2.46501 \\
\hline $\mathrm{CB}$ & 4.92613 & 4.91676 & 4.86414 & 4.90616 & 4.88974 & 4.88012 & 4.92311 & 4.88888 & 4.87945 \\
\hline $\mathrm{C} 4$ & 2.46204 & 2.46022 & 2.47501 & 2.45903 & 2.48298 & 2.49455 & 2.48020 & 2.45616 & 2.47925 \\
\hline CB4 & 4.92611 & 4.91890 & 4.88010 & 4.90533 & 4.86884 & 4.89142 & 4.92173 & 4.89206 & 4.86165 \\
\hline $\mathrm{C} 5$ & 2.46204 & 2.46022 & 2.47501 & 2.49004 & 2.48298 & 2.47728 & 2.48020 & 2.48423 & 2.47925 \\
\hline CB5 & 4.92611 & 4.91890 & 4.88010 & 4.88500 & 4.86884 & 4.88019 & 4.92173 & 4.87245 & 4.86165 \\
\hline \multirow[t]{2}{*}{ WIX } & - & - & - & $14.24 \%$ & $10.91 \%$ & $4.02 \%$ & $0.00 \%$ & $7.57 \%$ & $4.56 \%$ \\
\hline & $\pi_{47}$ & $\pi_{48}$ & $\pi_{49}$ & $\pi_{50}$ & $\pi_{51}$ & $\pi_{52}$ & $\pi 53$ & $\pi_{54}$ & $\pi_{55}$ \\
\hline $\mathrm{C} 1$ & 2.46134 & 2.46485 & 2.46001 & 2.46423 & 2.46134 & 2.46485 & 2.46178 & 2.46020 & 2.46020 \\
\hline $\mathrm{C} 2$ & 2.46134 & 2.46485 & 2.46134 & 2.46485 & 2.46001 & 2.46423 & 2.46020 & 2.46178 & 2.46020 \\
\hline $\mathrm{C} 3$ & 2.46001 & 2.46423 & 2.46134 & 2.46485 & 2.46134 & 2.46485 & 2.46020 & 2.46020 & 2.46178 \\
\hline $\mathrm{CB}$ & 4.89956 & 4.88581 & 4.89956 & 4.88581 & 4.89956 & 4.88581 & 4.89998 & 4.89998 & 4.89998 \\
\hline $\mathrm{C} 4$ & 2.45792 & 2.48157 & 2.45792 & 2.48157 & 2.45792 & 2.48157 & 2.45865 & 2.45865 & 2.45865 \\
\hline CB4 & 4.90027 & 4.86610 & 4.90027 & 4.86610 & 4.90027 & 4.86610 & 4.89741 & 4.89741 & 4.89741 \\
\hline $\mathrm{C} 5$ & 2.48786 & 2.48157 & 2.48786 & 2.48157 & 2.48786 & 2.48157 & 2.48772 & 2.48772 & 2.48772 \\
\hline CB5 & 4.88021 & 4.86610 & 4.88021 & 4.86610 & 4.88021 & 4.86610 & 4.87990 & 4.87990 & 4.87990 \\
\hline \multirow[t]{2}{*}{ WIX } & $11.29 \%$ & $8.07 \%$ & $11.29 \%$ & $8.07 \%$ & $11.29 \%$ & $8.07 \%$ & $10.54 \%$ & $10.54 \%$ & $10.54 \%$ \\
\hline & $\pi_{56}$ & $\pi_{57}$ & $\pi_{58}$ & $\pi_{59}$ & $\pi_{60}$ & $\pi_{61}$ & $\pi_{62}$ & $\pi_{63}$ & $\pi_{64}$ \\
\hline $\mathrm{C} 1$ & 2.46050 & 2.46050 & 2.46076 & 2.46188 & 2.46188 & 2.45875 & 2.46147 & 2.46064 & 2.48331 \\
\hline $\mathrm{C} 2$ & 2.46050 & 2.46076 & 2.46050 & 2.46188 & 2.45875 & 2.46188 & 2.46147 & 2.46064 & 2.48331 \\
\hline $\mathrm{C} 3$ & 2.46076 & 2.46050 & 2.46050 & 2.45875 & 2.46188 & 2.46188 & 2.46147 & 2.46064 & 2.48331 \\
\hline $\mathrm{CB}$ & 4.89403 & 4.89403 & 4.89403 & 4.88962 & 4.88962 & 4.88962 & 4.87771 & 4.87236 & 4.79249 \\
\hline $\mathrm{C} 4$ & 2.45757 & 2.45757 & 2.45757 & 2.45783 & 2.45783 & 2.45783 & 2.45660 & 2.45695 & 2.48102 \\
\hline CB4 & 4.89298 & 4.89298 & 4.89298 & 4.88715 & 4.88715 & 4.88715 & 4.87647 & 4.87132 & 4.78536 \\
\hline $\mathrm{C} 5$ & 2.48573 & 2.48573 & 2.48573 & 2.48401 & 2.48401 & 2.48401 & 2.47968 & 2.45695 & 2.48102 \\
\hline CB5 & 4.87562 & 4.87562 & 4.87562 & 4.87194 & 4.87194 & 4.87194 & 4.86300 & 4.87132 & 4.78536 \\
\hline WIX & $7.78 \%$ & $7.78 \%$ & $7.78 \%$ & $6.23 \%$ & $6.23 \%$ & $6.23 \%$ & $2.54 \%$ & - & - \\
\hline
\end{tabular}


In $s c_{2}^{P / A}$ we assume the following parameter values for the matrices $\rho, \varsigma, \delta$ defined in Appendix B: ${ }^{19}$

$$
\begin{aligned}
\rho:=\varsigma:=\left[\begin{array}{lllll}
0 & 1 / 15 & 1 / 15 & 2 / 15 & 2 / 15 \\
4 / 35 & 0 & 2 / 35 & 4 / 35 & 4 / 35 \\
4 / 35 & 2 / 35 & 0 & 4 / 35 & 4 / 35 \\
2 / 15 & 1 / 15 & 1 / 15 & 0 & 2 / 15 \\
2 / 15 & 1 / 15 & 1 / 15 & 2 / 15 & 0
\end{array}\right] \text { and } \\
\delta:=\left[\begin{array}{lllll}
-4 / 10 & 1 / 15 & 1 / 15 & 2 / 15 & 2 / 15 \\
4 / 35 & -4 / 10 & 2 / 35 & 4 / 35 & 4 / 35 \\
4 / 35 & 2 / 35 & -4 / 10 & 4 / 35 & 4 / 35 \\
2 / 15 & 1 / 15 & 1 / 15 & -4 / 10 & 2 / 15 \\
2 / 15 & 1 / 15 & 1 / 15 & 2 / 15 & -4 / 10
\end{array}\right]
\end{aligned}
$$

Open Access This article is distributed under the terms of the Creative Commons Attribution Noncommercial License which permits any noncommercial use, distribution, and reproduction in any medium, provided the original author(s) and source are credited.

\section{References}

van Aarle B, Di Bartolomeo G, Engwerda J, Plasmans J (2002), "Coalitions and dynamic interactions between fiscal and monetary authorities in the EMU". Ifo Studien 48(2):207-229

van Aarle B, Di Bartolomeo G, Engwerda J, Plasmans J (2004) "Policy- makers' Coalitions and Stabilization Policies in the EMU'. JEcon 82(1):1-24

Angeloni, I., A. Kashyap, B. Mojon and D. Terlizzese (2002), "Monetary transmission in the Euro-area: Where do we stand?", ECB Working Paper No. 114, Frankfurt.

Di Bartolomeo G, Engwerda J, Plasmans J, van Aarle B (2006), "Staying together or breaking apart: Policy-makers' endogenous coalitions formation in the European Economic and Monetary Union", Computers and Operations Research, 33:438-463.

Bohn F (2004) Monetary Union and the Interest-Exchange Rate Trade-off. Open econ 15:111-141

Boone L, and Maurel M (1999), "Economic convergence of the CEECs with the EU", CEPR Discussion Paper no.2018.

Engwerda J, van Aarle B, Plasmans J (1999) The (in) finite horizon open- loop Nash LQ game: An application to the EMU. Ann Oper Res 88:251-273

Engwerda J, van Aarle B, Plasmans J (2002) Cooperative and non- cooperative fiscal stabilisation policies in the EMU. J. econ. dyn. control 26:451-481

European Commission (2001), "Public finances in EMU - 2001", European Economy Reports and Studies, No. 3, Brussels.

European Parliament (1999), "EMU and enlargement: A review of policy issues", Working Paper 12/99 Directorate-General for Research.

Favero C, Freixas X, Persson T, Wyplosz C (2000) One money many countries, monitoring the European Central Bank 2. Center for Economic Policy Research, London

Fidrmuc J, and Korhonen I (2001), "Similarity of supply and demand shocks between the euro area and the CEECs", BOFIT Discussion Paper 2001/14.

von Hagen J, Lutz S (1996) Fiscal and Monetary Policies on the Way to EMU. Open econ. rev. 7:299-325

${ }^{19}$ The off-diagonal elements of these matrices are the direct spillovers. For Appendix B, see www.ua.ac. be/joseph.plasmans. 
Hooper, P., K. Johnson and J. Marquez (1998), “Trade elasticities for G-7 countries”, International Finance Discussion Paper No. 609, Board of Governors of the Federal Reserve System, Washington DC.

Hughes Hallett, A.J. and P. McAdam (1997), "Fiscal Deficit Reductions in Line With the Maastricht Criteria for Monetary Union: An Empirical Analysis" in J. Frieder, D. Gros, E. Jones (eds.), Towards European Monetary Union: Problems and Prospects, Cambridge University Press.

Laxton, D., P. Isard, H. Faruqee, E. Prasad and B. Turtleboom (1998), "MULTI- MOD Mark III - The Core Dynamic and Steady-State Models", IMF Occasional Paper No. 164, Washington DC.

Michalak, T., J. Plasmans and J. Engwerda (2006), "Models of endogenous coalition formation between fiscal and monetary authorities in the presence of a monetary union", Working Paper, University of Antwerp, 39 pages.

Plasmans, J., J. Engwerda, B. van Aarle, and G. Di Bartolomeo (2006), Dynamic Modelling of Monetary and Fiscal Cooperation Among Nations, Springer Verlag, Berlin, 319 pages.

Smets, F. (2000), "What horizon for price stability", ECB Working Paper No. 24, Frankfurt. 